\title{
Hematoma Recurrence in Burr Hole Drainage Compared to Burr Hole Irrigation as Treatment of Chronic Subdural Hematoma: A Systematic Review and Meta-analysis
}

\author{
Sri Maliawan ${ }^{1}$, Made Bhuwana Putra ${ }^{2}$, Tjokorda GB Mahadewa $^{1 *}$, I Putu Eka Widyadharma ${ }^{3}$ \\ ${ }^{1}$ Department of Neurosurgery, Faculty of Medicine, Udayana University, Sanglah General Hospital, Bali, Indonesia; ${ }^{2}$ Department \\ of Neurosurgery, Mangusada General Hospital, Badung Regency, Bali, Indonesia; ${ }^{3}$ Department of Neurology, Faculty of \\ Medicine, Udayana University, Sanglah General Hospital, Bali, Indonesia
}

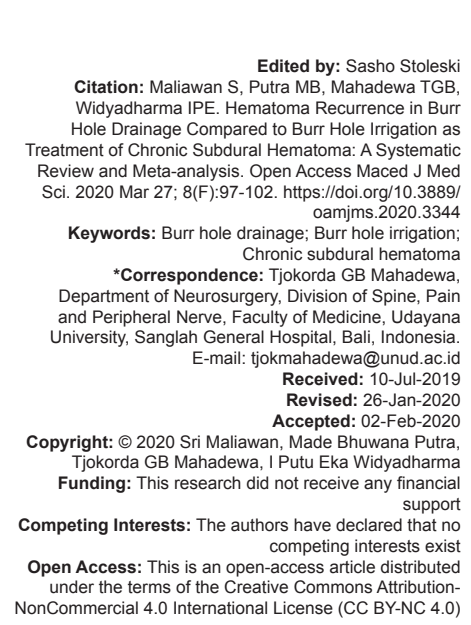

\begin{abstract}
BACKGROUND: Subdural hematoma is a common phenomenon following a traumatic brain injury where a hematoma is formed below the dura mater of brain meningeal layer, usually with a coup-contrecoup mechanism of injury. The chronic counterpart of subdural hematoma is frequently occurring in elderly patients. There are several techniques being used by many practitioners, including burr hole with or without irrigation, with little evidence of which technique is favorable, especially in terms of recurrence rates following the procedure.
\end{abstract}

AIM: This study aimed to compare the recurrences of chronic subdural hematoma (CSDH) following burr hole with and without saline irrigation technique by systematic review and meta-analysis.

METHODS: This study included all articles that describe the two specified burr hole techniques in treating patients with a CSDH. We extracted the eligibility criteria into keywords using Boolean Operator. In this study, we used keywords (CSDH) and (burr hole) and (irrigation) and ((drainage) or no irrigation)) in PubMed, directory of open access journal, and Google Scholar database.

RESULTS: This study included seven retrospective cohort studies from 2002 to 2017 with a total of 635 samples. The incidence of hematoma recurrences between burr hole irrigation and burr hole drainage was $14.7 \%$ and $12.0 \%$, respectively. Based on random effect model with high heterogeneity $\left(I^{2}=60 \% ; X^{2}=14.92 ; p=0.02\right)$, pooled risk ratio between burr hole irrigation and burr hole drainage on hematoma recurrences was $1.05(p=0.92 ; 95 \%$ confidence interval, 0.43-2.54).

CONCLUSION: There was no superiority between one procedure toward other in preventing recurrences of chronic subdural hematoma

\section{Introduction}

A subdural hematoma is a common phenomenon following a traumatic brain injury where a hematoma is formed below the dura mater part of brain meningeal layer following a traumatic head injury [1]. Acute subdural hematoma $(\mathrm{ASDH})$ can have a rapid progression and potentially devastating without early management. On the other hand, the chronic subdural hematoma $(\mathrm{CSDH})$ is usually progressing slower than the acute one, usually following a mild head injury [1]. $\mathrm{CSDH}$ frequently occurs in the elderly population due to brain atrophy, thus increasing the susceptibility of developing a potential space for a hematoma to build up [1], [2]. The exact pathophysiology of CSDH remains unclear [2]. The role of pseudocapsules in the process of $\mathrm{CSDH}$ has become a recent issue. Repetitive bleeding from the fragile outer membrane of sinusoidal vessel, along with high expression of both fibrinolytic and coagulation process, create a vicious cycle causing further development of hemorrhagic events [2], [3].
Thrombomodulin activation also plays a role in $\mathrm{CSDH}$ development [4]. The high recurrence rate is one of the biggest problems in treating $\mathrm{CSDH}$; pseudocapsule with septa becomes one of the risk factors for recurrence cases [1], [3].

At present, there are a handful of surgical technique mainstay in managing $\mathrm{CSDH}$ from craniotomy with subsequent membranectomy, twist drill craniotomy, or burr hole craniotomy with no well-established firstline management standard [5], [6], [7]. Among those, burr hole craniotomy has been widely accepted with some debate over whether to do intraoperative irrigation or not [2], [3]. Some author proposed that intraoperative irrigation will break the CSDH capsule, especially if there is more than one capsule which can be hard to evaluate through a burr hole and reduce the recurrence rate, and the other benefit is that it can wash out the inflammatory cytokines that reside in the cavity, which is thought as one of the factors to cause recurrence [7], [8], [9]. Despite that, this actually is still remains in question with conflicting results. 
This study presents a systematic review and metaanalysis using the available evidence to better understand which one of the two methods (burr hole craniotomy with irrigation or without irrigation) is favorable, focusing in terms of recurrence rate following the procedures.

\section{Methods}

\section{Eligibility criteria}

Eligibility criteria were created based on the Patient, Intervention, Comparision, Outcome (PICO) framework. PICO criteria can be seen in Table 1.

Table 1: PICO criteria of the study

\begin{tabular}{ll}
\hline Patient & CSDH \\
\hline Intervention & Burr hole irrigation \\
Comparator & Burr hole drainage \\
Outcome & Recurrence of hematoma \\
\hline CSDH: Chronic subdural hematoma. &
\end{tabular}

\section{Type of studies}

This review included all studies comparing burr hole drainage and burr hole irrigation in CSDH patients. We exclude review, animal, anatomic, cadaveric, qualitative, and economic studies. If there are articles from the same author and from the same institution, we conduct a review of the sample so that there is no duplication in the meta-analysis.

We included studies published in Bahasa and English. Another language was translated using Google Translate and decided by the author whether to include them or not. There was no restriction regarding the year of publication.

\section{Type of participants}

This review included studies with the adult participant (age 18 years or older) of both genders who have suffered CSDH. CSDH was defined as a hematoma in potential space between dura mater and arachnoid that was confirmed by crescentic hypo- or mixed dense lesion in head computed tomography (CT) scan. Participants of all nationalities and setting were included in the study. Participants with other head injury were excluded from this review.

\section{Type of interventions}

The reviewed surgical interventions were burr hole drainage and burr hole irrigation. Burr hole drainage was defined as procedure inserting a tube to subdural space to drain the hematoma without irrigation using saline solution. Burr hole irrigation was defined as drainage of subdural hematoma by inserting a tube to subdural space accompany with irrigation using saline solution. We excluded studies that did not describe the surgical procedure and combine the technique of interest with other techniques.

\section{Type of outcomes}

The investigated outcome in this review was a recurrence of a CSDH after the surgical procedure. Recurrence of $\mathrm{CSDH}$ was defined as reappearance or increasing of hematoma on the same side as the previously operated side within 1 year with neurological symptoms, thus repeated operation is needed.

\section{Search strategy \\ Information sources}

We extracted the eligibility criteria (PICO) into keywords using Boolean Operator. In this study, we used keywords ((CSDH) and (burr hole) and (irrigation) and ((drainage) or no irrigation) in PubMed database. We also performed an electronic search using Google Scholar and Directory of Open Access Journal as a search engine to find an eligible journal.

\section{Study selection}

The study selection process was performed by two authors (BP and EM) to reduce the possibility of discarding relevant studies. The decision of the third and fourth authors was used when a disagreement occurred. Duplicate records were removed. Titles and abstracts were screened and irrelevant studies were removed. Studies that passed the first screening were further evaluated for the compliance of the inclusion and exclusion criteria of this review. Finally, the studies were further evaluated for their quality before included in this review.

\section{Data collection process}

Electronic data collection form was used to collect data from each author. The collected data by each author will be merged and be managed with software Review Manager 5.3.

\section{Data items}

The data items were the author's name, year of publication, method, sample size, diagnosis of the participant, age, surgical technique, and recurrence rate data. The recurrence rate data are calculated for its relative risk $(R R)$ then enters the meta-analysis.

\section{Assessment of quality of the study}

Studies that complied with inclusion and exclusion criteria are assessed for their quality to ensure 
the validity and reliability of the studies. This process was done independently by two authors using a standardized critical appraisal tool to minimize the possibility of bias in study selection. The critical appraisal tool in this study was The Joanna Briggs Institute (JBI) critical appraisal tool based on study design. The decision of the third and fourth authors was used when a disagreement occurred.

Cutoff point was used to determine the quality of the study. Cutoff point in this review was half of the total score in each JBI critical appraisal checklist. The low-quality study was defined as a score below the cutoff point while conversely was termed a high-quality study.

\section{Synthesis of result}

The RR of hematoma recurrences was pooled and analyzed. Meta-analyses were performed using software Review Manager 5.3. Random effect model was used due to high heterogeneity among studies.

\section{Results}

\section{Study selection}

Using the initial search strategy, we found a total of 432 studies. We excluded 420 articles because of the non-relevant title. That left us 12 articles with a relevant title. Based on abstract screening, we excluded five articles. Studies that included ASDH or using different surgical techniques were excluded from the study. After screening and qualitative evaluation were done, we finally have seven articles used in this study. PRISMA study flow diagram can be seen in Figure 1.

\section{Study characteristics}

We included seven full-text articles which are six retrospective cohort studies and one prospective study. The publication year of these articles varied between 2002 and 2017, with a total of 635 samples included in the study. The summary of finding can be seen in Table 2.

\section{Risk of bias within studies}

The risk of bias was analyzed using JBI critical appraisal tool for cohort studies. All seven articles included in this study were passed the quality evaluation. Complete result of the risk of bias can be seen in Table 3 .

\section{Synthesis of Result}

As shown in Figure 2, the incidence of hematoma recurrence between burr hole irrigation and burr hole drainage was $14.7 \%$ and $12 \%$, respectively. Based on random effect model with high heterogeneity $\left(I^{2}=60 \% ; X^{2}=14.92 ; p=0.02\right)$, pooled risk ratio
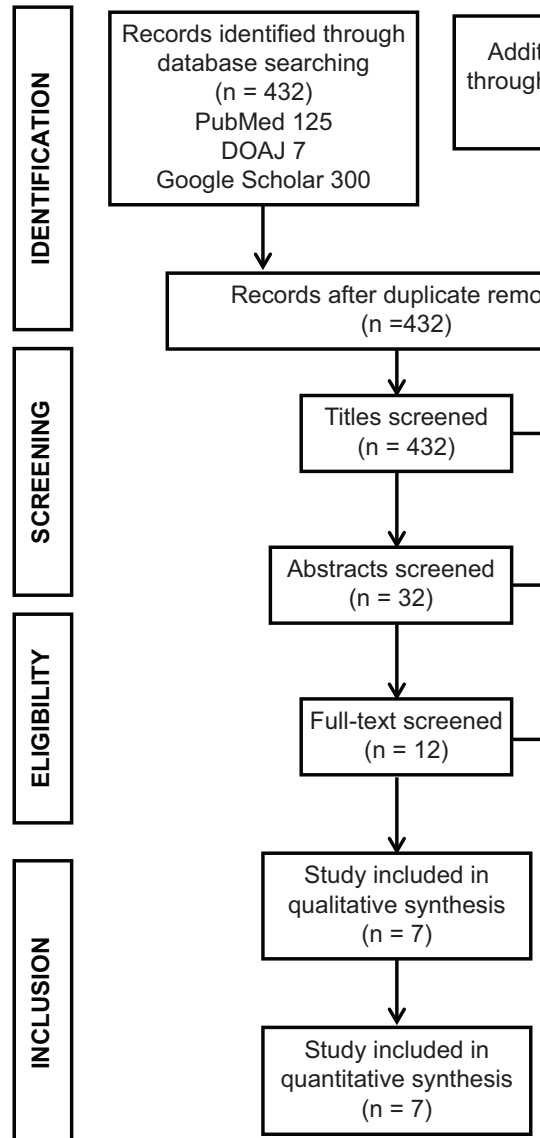

Figure 1: PRISMA flow diagram

Table 2: Summary of findings for the main comparison

\begin{tabular}{|c|c|c|c|c|c|c|c|c|}
\hline Author & Type of study & Level of evidence & Condition & Intervention & $\mathrm{n}$ & Control & $\mathrm{n}$ & Outcome \\
\hline $\begin{array}{l}\text { Jang et al. } \\
(2015)\end{array}$ & Retrospective cohort & $2 \mathrm{~b}$ & $\begin{array}{l}\text { CSDH patients who underwent surgery between } \\
\text { January } 2010 \text { and June } 2014\end{array}$ & $\mathrm{BI}$ & 30 & BD & 32 & $\begin{array}{l}\text { Bl: } 3 \text { recurrences }(10.0 \%) \\
\text { BD: } 8 \text { recurrences }(25.0 \%)\end{array}$ \\
\hline $\begin{array}{l}\text { Ishibashi et al. } \\
\text { (2011) }\end{array}$ & Retrospective cohort & $2 b$ & $\begin{array}{l}\text { Adult who underwent surgery for CSDH between } \\
\text { January } 1998 \text { and December } 2009\end{array}$ & $\mathrm{BI}$ & 34 & BD & 58 & $\begin{array}{l}\text { BI: } 1 \text { recurrence }(2.9 \%) \\
\text { BD: } 6 \text { recurrences }(10.3 \%)\end{array}$ \\
\hline $\begin{array}{l}\text { Wang et al. } \\
\text { (2017) }\end{array}$ & Retrospective cohort & $2 b$ & $\begin{array}{l}\text { Adult who had unilateral CSDH who was } \\
\text { admitted and underwent surgery from January } \\
2013 \text { to December } 2016\end{array}$ & $\mathrm{BI}$ & 88 & BD & 63 & $\begin{array}{l}\mathrm{BI}: 6 \text { recurrences }(6.8 \%) \\
\text { BD: } 5 \text { recurrences }(7.9 \%)\end{array}$ \\
\hline $\begin{array}{l}\text { Iftikhar et al. } \\
(2014)\end{array}$ & Retrospective cohort & $2 b$ & $\begin{array}{l}\text { Adult who had CSDH and underwent burr hole } \\
\text { evacuation }\end{array}$ & $\mathrm{BI}$ & 34 & BD & 22 & $\begin{array}{l}\text { BI: } 6 \text { recurrences }(17.6 \%) \\
\text { BD: } 2 \text { recurrences }(9.1 \%)\end{array}$ \\
\hline Kim et al. (2014) & Retrospective cohort & $2 b$ & Adult who had CSDH with unilateral hematoma & $\mathrm{BI}$ & 114 & $\mathrm{BD}$ & 38 & $\begin{array}{l}\text { BI: } 28 \text { recurrences }(24.5 \%) \\
\text { BD: } 1 \text { recurrence }(2.6 \%)\end{array}$ \\
\hline $\begin{array}{l}\text { Okada et al. } \\
(2002)\end{array}$ & Prospective cohort & $1 \mathrm{~b}$ & $\begin{array}{l}\text { Adult who had CSDH underwent surgery from } \\
\text { February } 1996 \text { to February } 1999\end{array}$ & $\mathrm{BI}$ & 20 & BD & 20 & $\begin{array}{l}\mathrm{BI}: 5 \text { recurrences }(25.0 \%) \\
\text { BD: } 1 \text { recurrences }(5 \%)\end{array}$ \\
\hline $\begin{array}{l}\text { Zakaraia et al. } \\
(2008)\end{array}$ & Retrospective cohort & $2 b$ & CSDH patients who received surgical treatment & $\mathrm{BI}$ & 40 & $\mathrm{BD}$ & 42 & $\begin{array}{l}\text { BI: } 4 \text { recurrences }(10 \%) \\
\text { BD: } 10 \text { recurrences }(23.8 \%)\end{array}$ \\
\hline
\end{tabular}


between burr hole irrigation and burr hole drainage on hematoma recurrence was 1.05 ( $p=0.92 ; 95 \%$ confidence interval: 0.43-2.54).

\section{Discussion}

$\mathrm{CSDH}$ is one of the most common problems in the neurosurgical field. There are two major proposed pathophysiologies of CSDH development. The first one is the osmotic gradient theory, where there is an increase of protein content inside CSDH cavity which in turn increases the oncotic pressure inside the capsule and draws fluid from neighboring vessels [10]. The other more widely accepted model is that there is a recurrent hemorrhage from the $\mathrm{CSDH}$ capsule followed by hypercoagulation and local hyperfibrinolysis [2], [4]. CSDH usually occurs following trauma; in some cases, the trauma might be so trivial that the patient can barely remember. After 3-4 weeks, a neomembrane forms from the dural border layer cell [2]. While the inner membrane has few blood vessels, the outer membrane is thick with numerous fragile vessels. These vessels are easily injured by transmitted pulsation from the brain, head trauma, or even head movement [4].

The recurrence of the cases after surgical procedure, that further might need reoperation, has been one of the prominent problems with $\mathrm{CSDH}$, this might be related to several factors, including the nature

Table 3: Risk of bias summary

\begin{tabular}{|c|c|c|c|c|c|c|c|c|c|c|c|c|}
\hline \multirow[t]{2}{*}{ Study (Year) } & \multicolumn{12}{|c|}{ Question no. } \\
\hline & 1 & 2 & 3 & 4 & 5 & 6 & 7 & 8 & 9 & 10 & 11 & Total \\
\hline \multicolumn{13}{|l|}{ Reviewer: BP } \\
\hline Jang et al. (2015) & $\mathrm{Y}$ & $\mathrm{Y}$ & $\mathrm{Y}$ & $\mathrm{Y}$ & $\mathrm{Y}$ & $\mathrm{Y}$ & $\mathrm{Y}$ & $\mathrm{Y}$ & $\mathrm{Y}$ & $\mathrm{N}$ & $\mathrm{Y}$ & $10 / 11$ \\
\hline Ishibasi et al. (2011) & $\mathrm{Y}$ & $\mathrm{Y}$ & $\mathrm{Y}$ & $\mathrm{Y}$ & $\mathrm{Y}$ & $\mathrm{Y}$ & $\mathrm{Y}$ & $\mathrm{Y}$ & $\mathrm{Y}$ & $\mathrm{N}$ & $\mathrm{Y}$ & $10 / 11$ \\
\hline Wang et al. (2017) & $\mathrm{Y}$ & $\mathrm{Y}$ & $\mathrm{Y}$ & Y & $\mathrm{N}$ & $\mathrm{Y}$ & $\mathrm{Y}$ & $\mathrm{Y}$ & $\mathrm{Y}$ & $\mathrm{N}$ & $\mathrm{Y}$ & $9 / 11$ \\
\hline Iftikhar et al. (2014) & $\mathrm{Y}$ & $\mathrm{Y}$ & $\mathrm{Y}$ & $\mathrm{Y}$ & $\mathrm{N}$ & $\mathrm{Y}$ & $\mathrm{N}$ & $\mathrm{Y}$ & $\mathrm{Y}$ & $\mathrm{N}$ & $\mathrm{Y}$ & $8 / 11$ \\
\hline Kim et al. (2014) & $\mathrm{Y}$ & $\mathrm{Y}$ & $\mathrm{Y}$ & $\mathrm{Y}$ & $\mathrm{N}$ & $\mathrm{Y}$ & $\mathrm{Y}$ & $\mathrm{Y}$ & $\mathrm{Y}$ & $\mathrm{N}$ & $\mathrm{Y}$ & $9 / 11$ \\
\hline Okada et al. (2002) & $\mathrm{Y}$ & $\mathrm{Y}$ & $\mathrm{Y}$ & $\mathrm{N}$ & $\mathrm{Y}$ & $\mathrm{Y}$ & $\mathrm{Y}$ & $\mathrm{Y}$ & $\mathrm{Y}$ & $\mathrm{N}$ & $\mathrm{Y}$ & $9 / 11$ \\
\hline Zakaraia et al. (2008) & $\mathrm{Y}$ & $\mathrm{Y}$ & $\mathrm{Y}$ & $\mathrm{Y}$ & $\mathrm{Y}$ & $\mathrm{Y}$ & $\mathrm{Y}$ & $\mathrm{Y}$ & $\mathrm{Y}$ & $\mathrm{N}$ & $\mathrm{Y}$ & $10 / 11$ \\
\hline \multicolumn{13}{|l|}{ Reviewer: EM } \\
\hline Jang et al. (2015) & $\mathrm{Y}$ & $\mathrm{Y}$ & $\mathrm{Y}$ & $\mathrm{Y}$ & $\mathrm{Y}$ & $\mathrm{Y}$ & $\mathrm{Y}$ & $\mathrm{Y}$ & $\mathrm{Y}$ & $\mathrm{N}$ & $\mathrm{Y}$ & $10 / 11$ \\
\hline Ishibasi et al. (2011) & $\mathrm{Y}$ & $\mathrm{Y}$ & $\mathrm{Y}$ & $\mathrm{Y}$ & $\mathrm{Y}$ & $\mathrm{Y}$ & $\mathrm{Y}$ & $\mathrm{Y}$ & $\mathrm{Y}$ & $\mathrm{N}$ & $\mathrm{Y}$ & $10 / 11$ \\
\hline Wang et al. (2017) & $\mathrm{Y}$ & $\mathrm{Y}$ & $\mathrm{Y}$ & $\mathrm{Y}$ & $\mathrm{N}$ & $\mathrm{Y}$ & $\mathrm{Y}$ & $\mathrm{Y}$ & $\mathrm{Y}$ & $\mathrm{N}$ & $\mathrm{Y}$ & $9 / 11$ \\
\hline Iftikhar et al. (2014) & $\mathrm{Y}$ & $\mathrm{Y}$ & $\mathrm{Y}$ & $\mathrm{Y}$ & $\mathrm{N}$ & $\mathrm{Y}$ & $\mathrm{N}$ & $\mathrm{Y}$ & $\mathrm{Y}$ & $\mathrm{N}$ & $\mathrm{Y}$ & $8 / 11$ \\
\hline Kim et al. (2014) & $\mathrm{Y}$ & $\mathrm{Y}$ & $\mathrm{Y}$ & $\mathrm{Y}$ & $\mathrm{N}$ & $\mathrm{Y}$ & $\mathrm{Y}$ & $\mathrm{Y}$ & $\mathrm{Y}$ & $\mathrm{N}$ & $\mathrm{Y}$ & $9 / 11$ \\
\hline Okada et al. (2002) & $\mathrm{Y}$ & $\mathrm{Y}$ & $\mathrm{Y}$ & $\mathrm{N}$ & $\mathrm{Y}$ & $\mathrm{Y}$ & $\mathrm{Y}$ & $\mathrm{Y}$ & $\mathrm{Y}$ & $\mathrm{N}$ & $\mathrm{Y}$ & $9 / 11$ \\
\hline Zakaraia et al. (2008) & $\mathrm{Y}$ & $\mathrm{Y}$ & $\mathrm{Y}$ & $\mathrm{Y}$ & $\mathrm{Y}$ & $\mathrm{Y}$ & $\mathrm{Y}$ & $\mathrm{Y}$ & $\mathrm{Y}$ & $\mathrm{N}$ & $\mathrm{Y}$ & $10 / 11$ \\
\hline
\end{tabular}

of pathophysiology of CSDH itself, older age concerning lesser ability of the brain to re-expand after surgical evacuation, bilateral $\mathrm{CSDH}$, large initial hematoma, and anticoagulant use. The high concentration of inflammatory mediator such as interleukin 6 and growth factors in subdural fluid is also thought to increase the recurrence rate [2], [5], [6], [10], [11], [12]. Kim et al. mentioned that the history of malignant neoplasm and type of hematoma found in CT evaluation is also associated with the recurrence of CSDH [13]. While there are some options regarding the types of fluid to be used for irrigation, all of the studies included in this review used normal saline.

In this review, some of the studies' results favor irrigation [9], [14], [15], [16], while the other showed that the recurrence rate was lower on drainage only group [13], [17], [18]. Our result has it that although the incident was slightly higher in the irrigation group, there is actually no significant difference of the recurrence rate whether irrigation was done or not. It was proposed by some authors that irrigation may promote lower recurrence by washing out the hematoma along with the inflammatory cytokines and growth factors such as vascular endothelial growth factor and fibroblast growth factor which is thought as one of the factors that can increase the risk of recurrences [7], [8], [9]. Some authors disagree and believe that rapid cerebral decompression by means of irrigation might actually cause cortical and vascular injury and promote recurrences [15], [18]. Irrigation also may cause a rapid decrease of intracranial pressure, which in turn can cause new vessel damage [16], [17], [18]. A sudden normalization of cerebral blood flow on a defected blood vessel with disrupted autoregulation may also play a role in further hemorrhage following the procedure [19], [20] and this in contrast with the drainage only procedure which decreases the pressure in a more gradual manner [16]. By irrigating the subdural cavity, there is also a higher chance that air can enter, thus a higher chance that pneumocephalus may develop [18]. While pneumocephalus commonly occurs after craniotomy procedure, a higher volume of this event may restrict the expansion of the brain, which might lead to a higher chance of recurrences [21]. The downside of burr hole drainage only is that it is hard to evaluate if there are

\begin{tabular}{|c|c|c|c|c|c|c|c|c|c|c|}
\hline \multirow[b]{2}{*}{ Study or Subgroup } & \multicolumn{2}{|c|}{ Burrhole Irrigation } & \multicolumn{2}{|c|}{ Burrhole Drainage } & \multirow[b]{2}{*}{ Weight } & \multirow{2}{*}{$\begin{array}{c}\text { Risk Ratio } \\
\text { M-H, Random, } 95 \% \mathrm{Cl}\end{array}$} & \multirow{2}{*}{\multicolumn{4}{|c|}{$\begin{array}{c}\text { Risk Ratio } \\
\mathrm{M}-\mathrm{H}, \text { Random, } 95 \% \mathrm{Cl}\end{array}$}} \\
\hline & Events & Total & Events & Total & & & & & & \\
\hline Iftikhar 2014 & 6 & 34 & 2 & 22 & $14.5 \%$ & $1.94[0.43,8.77]$ & & & & \\
\hline Ishibashi 2011 & 1 & 34 & 6 & 58 & $10.6 \%$ & $0.28[0.04,2.26]$ & & & & \\
\hline Jang 2015 & 3 & 30 & 8 & 32 & $16.9 \%$ & $0.40[0.12,1.37]$ & & & & \\
\hline Kim 2014 & 28 & 114 & 1 & 38 & $11.3 \%$ & $9.33[1.31,66.30]$ & & & & \\
\hline Okada 2002 & 5 & 20 & 1 & 20 & $10.7 \%$ & $5.00[0.64,39.06]$ & & & & \\
\hline Wang 2017 & 6 & 88 & 5 & 63 & $17.7 \%$ & $0.86[0.27,2.69]$ & & & & \\
\hline Zakaraia 2008 & 4 & 40 & 10 & 42 & $18.3 \%$ & $0.42[0.14,1.23]$ & & & & \\
\hline Total $(95 \% \mathrm{Cl})$ & & 360 & & 275 & $100.0 \%$ & $1.05[0.43,2.54]$ & & & & \\
\hline Total events & 53 & & 33 & & & & & & & \\
\hline \multicolumn{7}{|c|}{$\begin{array}{l}\text { Heterogeneity: } \text { Tau }^{2}=0.82 ; \mathrm{Chi}^{2}=14.92, \mathrm{df}=6(P=0.02) ; I^{2}=60 \% \\
\text { Test for overall effect: } Z=0.10(P=0.92)\end{array}$} & 0.01 & $\begin{array}{c}0.1 \\
\text { Burrhole irrigation }\end{array}$ & $\begin{array}{c}10 \\
\text { Burrhole drainage }\end{array}$ & 100 \\
\hline
\end{tabular}

Figure 2: Forest plot comparing burr hole irrigation and burr hole drainage 
any other compartments of the developed membrane instead of just one. In some cases, then the hematoma increased and became recurrent case [18].

The limitation of this review is that none of the studies included in a randomized controlled trial. All the studies were non-randomized retrospective cohort; they might be prone to some biases, including selection, detection, attrition, and performance bias. Some studies also acknowledge the limited number of samples in their studies. There was no limitation regarding the follow-up time, as every study has different follow up time, especially for CT scan evaluation. Furthermore, it is possible that using our search strategy, we might actually miss other relevant articles.

\section{Conclusion}

There was no superiority between one procedure compare to other in preventing the recurrence of $\mathrm{CSDH}$. More studies have to be done to determine the best management in preventing the recurrence of $\mathrm{CSDH}$.

\section{References}

1. Sahyouni R, Goshtasbi K, Mahmoodi A, Tran DK, Chen JW. Chronic subdural hematoma: A historical and clinical perspective. World Neurosurg. 2017;108:948-53. https://doi. org/10.1016/j.wneu.2017.09.064

PMid:28935548

2. Shim YS, Park CO, Hyun DK, Park HC, Yoon SH. What are the causative factors for a slow, progressive enlargement of a chronic subdural hematoma? Yonsei Med J. 2007;48(2):210-7. https://doi.org/10.3349/ymj.2007.48.2.210

PMid:17461518

3. Mehta V, Harward SC, Sankey EW, Nayar G, Codd PJ. Evidence based diagnosis and management of chronic subdural hematoma: A review of the literature. J Clin Neurosci. 2018;50:7-15. https://doi.org/10.1016/j.jocn.2018.01.050 PMid:29428263

4. Murakami H, Hirose $Y$, Sagoh M, Shimizu K, Kojima M, Gotoh $\mathrm{K}$, et al. Why do chronic subdural hematomas continue to grow slowly and not coagulate? Role of thrombomodulin in the mechanism. J Neurosurg. 2002;96(5):877-84. https://doi. org/10.3171/jns.2002.96.5.0877

PMid:12005395

5. Torihashi K, Sadamasa N, Yoshida K, Narumi O, Chin M, Yamagata S. Independent predictors for recurrence of chronic subdural hematoma: A review of 343 consecutive surgical cases. Neurosurgery. 2008;63(6):1125-9. https://doi.org/10.1227/01. neu.0000335782.60059.17

PMid:19008766

6. Yamamoto $\mathrm{H}$, Hirashima $\mathrm{Y}$, Hamada $\mathrm{H}$, Hayashi $\mathrm{N}$, Origasa $\mathrm{H}$, Endo S. Independent predictors of recurrence of chronic subdural hematoma: Results of multivariate analysis performed using a logistic regression model. J Neurosurg. 2003;98(6):1217-21. https://doi.org/10.3171/jns.2003.98.6.1217

PMid:12816267

7. Kareem $\mathrm{H}$, Adams $\mathrm{H}$. A closed system irrigation and drainage technique for surgical evacuation of chronic subdural haematomas. F1000Res. 2018;7:619. https://doi.org/10.12688/ f1000research.14932.1

PMid:29904602

8. Ram Z, Hadani M, Sahar A, Spiegelmann R. Continuous irrigation-drainage of the subdural space for the treatment of chronic subdural haematoma. A prospective clinical trial. Acta Neurochir (Wien). 1993;120(1-2):40-3. https://doi.org/10.1007/ bf02001467

PMid:8434515

9. Jang KM, Kwon JT, Hwang SN, Park YS, Nam TK. Comparison of the outcomes and recurrence with three surgical techniques for chronic subdural hematoma: Single, double burr hole, and double burr hole drainage with irrigation. Korean J Neurotrauma. 2015;11(2):75-80. https://doi.org/10.13004/kjnt.2015.11.2.75 PMid:27169069

10. Adhiyaman V, Asghar M, Ganeshram KN, Bhowmick BK Chronic subdural haematoma in the elderly. Postgrad Med J. 2002;78(916):71-5. https://doi.org/10.1136/pmj.78.916.71 PMid: 11807186

11. Stroobandt G, Fransen P, Thauvoy C, Menard E. Pathogenetic factors in chronic subdural haematoma and causes of recurrence after drainage. Acta Neurochir (wien). 1995;137(12):6-14. https://doi.org/10.1007/bf02188772 PMid:8748860

12. Edlmann E, Giorgi-Coll S, Whitfield PC, Carpenter KL, Hutchinson PJ. Pathophysiology of chronic subdural haematoma: Inflammation, angiogenesis and implications for pharmacotherapy. J Neuroinflammation. 2017;14(1):108. https://doi.org/10.1186/s12974-017-0881-y PMid:28558815

13. Kim SS, Won JC, Kwon HS, Kim CH, Lee JH, Park TS, et al. Prevalence and clinical implications of painful diabetic peripheral neuropathy in Type 2 diabetes: Results from a nationwide hospital-based study of diabetic neuropathy in Korea. Diabetes Res Clin Pract. 2014;103(3):522-9. https://doi.org/10.1016/j. diabres.2013.12.003

PMid:24438877

14. Ishibashi A, Yokokura $\mathrm{Y}$, Adachi H. A comparative study of treatments for chronic subdural hematoma: Burr hole drainage versus burr hole drainage with irrigation. Kurume Med J. 2011;58(1):35-9. https://doi.org/10.2739/kurumemedj.58.35 PMid:22027196

15. Wang QP, Yuan Y, Guan JW, Jiang XB. A comparative study of irrigation versus no irrigation during burr hole craniostomy to treat chronic subdural hematoma. BMC Surg. 2017;17(1):99. https://doi.org/10.1186/s12893-017-0295-x PMid:28893217

16. Zakaraia AM, Adnan JS, Haspani MS, Naing NN, Abdullah JM Outcome of 2 different Types of operative techniques practiced for chronic subdural hematoma in Malaysia: An analysis. Surg Neurol. 2008;69(6):608-15. https://doi.org/10.1016/j. surneu.2007.01.054

PMid:18486703

17. Iftikhar M, Siddiqui UT, Rauf MY, Malik AO, Javed G Comparison of irrigation versus no irrigation during burr hole evacuation of chronic subdural hematoma. J Neurol Surg A Cent Eur Neurosurg. 2016;77(5):416-21. https://doi. org/10.1055/s-0035-1564049 PMid:27123748

18. Okada $\mathrm{Y}$, Akai $\mathrm{T}$, Okamoto $\mathrm{K}$, lida $\mathrm{T}$, Takata $\mathrm{H}$, lizuka $\mathrm{H}$ A comparative study of the treatment of chronic subdural 
hematoma-burr hole drainage versus burr hole irrigation Surg Neurol. 2002;57(6):405-9. https://doi.org/10.1016/ s0090-3019(02)00720-6

PMid:12176202

19. Eom KS, Kim TY, Park JT. Contralateral acute interdural haematoma occurring after burr hole drainage of chronic subdural haematoma. $\mathrm{Br} J$ Neurosurg. 2009;23(2):213-5. https://doi.org/10.1080/02688690802429202 PMid:19306184

20. Sun HL, Chang CJ, Hsieh CT. Contralateral acute subdural hematoma occurring after evacuation of subdural hematoma with coexistent contralateral subdural hygroma. Neurosciences (Riyadh). 2014;19(3):229. https://doi.org/10.13004/ jknts.2011.7.1.39

PMid:24983286

21. You CG, Zheng XS. Postoperative pneumocephalus increases the recurrence rate of chronic subdural hematoma. Clin Neurol Neurosurg. 2018;166:56-60. https://doi.org/10.1016/j. clineuro.2018.01.029

PMid:29408774 